\title{
Doses and forms of Azospirillum brasilense inoculation on maize crop
}

\author{
José M. K. Santini ${ }^{1}$, Salatiér Buzetti², Marcelo C. M. Teixeira Filho², \\ Fernando S. Galindo ${ }^{2}$, Daniel N. Coaguila ${ }^{1} \&$ Eduardo H. M. Boleta ${ }^{2}$ \\ ${ }^{1}$ Instituto de Ensino Superior de Rio Verde/ Departamento de Agronomia. Rio Verde, GO. E-mail: santini@faculdadeobjetivo.com.br (Corresponding author) - \\ ORCID: 0000-0001-5333-861X; tuheraldo@gmail.com - ORCID: 0000-0001-7177-6058 \\ ${ }^{2}$ Universidade Estadual Paulista/Faculdade de Engenharia/Departamento de Fitossanidade, Engenharia Rural e Solos. Ilha Solteira, SP. E-mail: sbuzetti@agr.feis.unesp.br - \\ ORCID: 0000-0003-2569-4750; mcmtf@yahoo.com.br - ORCID: 0000-0003-2303-3465; fs.galindo@yahoo.com.br - ORCID: 0000-0001-5118-7459; \\ eduardomarcandalli7@gmail.com - ORCID: 0000-0001-7969-8197
}

\section{Key words:}

diazotrophic bacteria plant growth promoters plant nutrition Zea mays L.

\begin{abstract}
A B S T R A C T
In search of a more sustainable agriculture, the use of beneficial microorganisms has been highlighted, because they are low-cost and can reduce the use of fertilizers and increase grain yield. The present study aimed to evaluate the efficiency of $A$. brasilense inoculation and the best form and dose of inoculation in maize, measuring the impact on some physical characteristics and on its nutrition. The experiment was conducted in a greenhouse, in Ilha Solteira, SP, Brazil, in a completely randomized design, with four replicates and eight treatments: 1) control; 2) Seed 1x; 3) Seed 2x; 4) Soil 1x; 5) Soil 2x; 6) Leaf 1x; 7) Leaf $2 x ; 8)$ Seed $1 x+$ Leaf $1 x$, respectively representing in each treatment the site and dose of application ( $1 \mathrm{x}$, dose recommended by the manufacturer; $2 \mathrm{x}$, twice the dose recommended by the manufacturer). No differences were found in any physical characteristics evaluated between treatments; however, for nutrient contents in the leaf tissue, there was effect on $\mathrm{Zn}$ content. It was concluded that, regardless of the presence of $A$. brasilense inoculation, forms or dose (in hybrid DKB 350), in general, there were no improvements in the characteristics evaluated.
\end{abstract}

\section{Palavras-chave:}

bactérias diazotróficas nutrição de plantas promotores de crescimento vegetal Zea mays L.

\section{Doses e formas de inoculação com Azospirillum brasilense na cultura do milho}

\section{R E S U M O}

Microrganismos benéficos vem sendo amplamente aplicados na agricultura, por possuírem baixo custo e possibilitarem a redução da utilização de adubos e incrementos na produtividade de grãos. Com o presente trabalho, objetivou-se determinar o efeito de doses e formas de aplicação do inoculante Azospirillum brasilense na nutrição de planta e na produção da cultura do milho. $\mathrm{O}$ experimento foi realizado em casa de vegetação, no município de Ilha Solteira, SP, em delineamento inteiramente ao acaso, com quatro repetições e oito tratamentos: 1) Testemunha; 2) Semente 1x; 3) Semente 2x; 4) Solo 1x; 5) Solo 2x; 6) Foliar 1x; 7) Foliar 2x; 8) Semente 1x + Foliar 1x, sendo, respectivamente dentro de cada tratamento, o local e a dose de aplicação (1x, dose recomendada pelo fabricante; $2 \mathrm{x}$, dobro da dose recomendada pelo fabricante). Não foram verificadas diferenças para os tratamentos avaliados, nas características avaliadas, já para as concentrações de nutrientes no tecido foliar, houve efeito somente para o $\mathrm{Zn}$. Concluiu-se que, independente da presença de inoculação, da forma ou da dose de A. brasilense avaliada, no híbrido DKB 350, de modo geral, não houve melhorias nas características avaliadas e na nutrição da cultura do milho.

Ref. 183761 - Received 08 Aug, 2017 • Accepted 28 Dec, 2017 • Published 30 Apr, 2018 


\section{INTRODUCTION}

Maize is one of the main grain crops in Brazil (CONAB, 2015). Its large importance leads to the study on new technologies, aiming at increments in yield and possible reductions in production costs.

Using A. brasilense is a very promising technology associated with various positive factors to the crops, such as in the induction of the production of phytohormones (Tien et al., 1979; Bashan et al., 2004), possibility of reduction of nitrogen fertilization (Hungria et al., 2010), root growth (Ferreira et al., 2013), higher accumulation of nutrients (Baldani et al., 1997) and increments in grain yield (Sala et al., 2007; Hungria et al., 2010).

Seed treatment is the most common form of inoculation. However, it is possible to obtain the same or better responses when inoculation is performed in other ways, such as in the leaves or in the sowing furrow (Martins et al., 2012; Berezoski et al., 2013).

With advances in technology, more products have been introduced in seed treatment, such as fungicides, insecticides, micronutrients and biostimulants, making it important to remove products from the treatment (without reduction in efficiency). In addition, according to Dartora et al. (2013), the use of chemical products in seed treatment may cause harmful effects on the microbiota, reducing inoculation efficiency, as also claimed by Pereira et al. (2010) and Costa et al. (2013).

Given the above, the different forms of $A$. brasilense inoculation can interfere with the dose to be used and they sometimes have the same efficiency as the traditional method (through seeds). Therefore, this study aimed to evaluate the best form and dose of $A$. brasilense inoculation in the maize crop, by measuring the response in its agronomic characteristics and nutrition.

\section{Material AND Methods}

The experiment was carried out in a greenhouse from July 11 to September 15, 2014, in the municipality of Ilha SolteiraSP, Brazil, geographically located between the parallels $22^{\circ} 25^{\prime}$ $5^{\prime \prime} \mathrm{S}$ and $51^{\circ} 20^{\prime} 30^{\prime \prime} \mathrm{W}$.

The experiment was conducted using pots with capacity for $5 \mathrm{~kg}$ filled with substrate of clayey Red Latosol (Santos et al., 2013). Initially, the substrate was sampled and chemical and physical analyses were carried out, according to the methodology proposed by Raij et al. (2001), obtaining the following results: $\mathrm{pH}\left(\mathrm{CaCl}_{2}\right)=5.5 ; \mathrm{OM}=26 \mathrm{~g} \mathrm{dm}^{-3} ; \mathrm{P}$ (resin) $=30 \mathrm{mg} \mathrm{dm}^{-3} ; \mathrm{S}=4 \mathrm{mg} \mathrm{dm}^{-3} ; \mathrm{K}=4.1 \mathrm{mmol}_{\mathrm{c}} \mathrm{dm}^{-3} ; \mathrm{Ca}=32$ $\mathrm{mmol}_{\mathrm{c}} \mathrm{dm}^{-3} ; \mathrm{Mg}=17 \mathrm{mmol}_{\mathrm{c}} \mathrm{dm}^{-3} ; \mathrm{Al}=0 \mathrm{mmol}_{\mathrm{c}} \mathrm{dm}^{-3} ; \mathrm{H}+\mathrm{Al}$ $=29 \mathrm{mmol} \mathrm{dm}^{-3} ; \mathrm{B}=0.16 \mathrm{mg} \mathrm{dm}^{-3} ; \mathrm{Cu}=7.1 \mathrm{mg} \mathrm{dm}^{-3} ; \mathrm{Fe}=28$ $\mathrm{mg} \mathrm{dm}{ }^{-3} ; \mathrm{Mn}=126.8 \mathrm{mg} \mathrm{dm}^{-3} ; \mathrm{Zn}=1.3 \mathrm{mg} \mathrm{dm}^{-3}$.

The experiment was set in completely randomized design with four replicates and eight treatments, evaluating forms and doses of $A$. brasilense inoculation: 1) Control (without inoculation); 2) Seed $1 \mathrm{x}$; 3) Seed 2x; 4) Soil 1x; 5) Soil 2x; 6) Leaf $1 \mathrm{x}$; 7) Leaf $2 \mathrm{x}$; 8) Seed $1 \mathrm{x}+$ Leaf $1 \mathrm{x}$, respectively representing the site and dose of application, in each treatment. The doses used followed the manufacturer's recommendations $\left(1 \mathrm{x}=100 \mathrm{~mL} \mathrm{ha}^{-1}\right.$ of the commercial product $)$ and double the recommended dose $\left(2 \mathrm{x}=200 \mathrm{~mL} \mathrm{ha}^{-1}\right.$ of the commercial product), for application through the seed, using the same proportion in the applications through leaves and soil.

Treatments were applied using an inoculant that contained the strains $\mathrm{AbV}_{5}$ and $\mathrm{AbV}_{6}$, with guarantee of at least $2 \times 10^{8}$ viable cells $\mathrm{mL}^{-1}$. For treatments through the seeds, inoculation was performed immediately before sowing. For applications on the leaves and in the soil, the product was diluted in water and a mixture volume equivalent to $140 \mathrm{~L} \mathrm{ha}^{-1}$ was applied. Inoculation in the soil was performed at sowing (in the sowing furrow) using an automatic micropipette, whereas the inoculation in the leaves was performed using a $\mathrm{CO}_{2}-$ pressurized backpack sprayer, with a full cone jet nozzle and constant pressure of $2.0 \mathrm{kgf} \mathrm{\textrm {cm } ^ { - 2 }}$.

Three seeds of the triple hybrid maize DKB 350 were sown in each pot and thinning was performed immediately after seedling emergence, leaving only one plant per pot until the end of the experiment [ 61 days after emergence (DAS), when all plants were at the reproductive stage, R1]. As maize plants were sown, the pots were fertilized with $8.3 \mathrm{~g}$ of the $06-12$ 08 formulation (equivalent to $500 \mathrm{~kg} \mathrm{ha}^{-1}$ ) and, as the plant reached the V5 stage, top-dressing fertilization was applied using $1.3 \mathrm{~g}$ of $\mathrm{N}_{\text {pot }}{ }^{-1}$ (equivalent to $80 \mathrm{~kg} \mathrm{~N} \mathrm{ha}^{-1}$ ). Along the entire experimental period, weeds were manually removed.

At $61 \mathrm{DAE}$, the following variables were evaluated: plant height, ear insertion height, stem diameter, root volume, leaf area, and dry matter of roots, stem, leaves, tassel; shoots and total.

Plant height and ear insertion height were measured using a tape measure. Stem diameter was measured with a caliper in the middle of the second internode (from the base).

To evaluate the roots, they were initially separated from the soil using running water at low pressure. Root volume was determined using a 250-mL graduated cylinder filled with water up to $150 \mathrm{~mL}$; after roots were immersed, the relative increase of volume was measured, considering $150 \mathrm{~mL}$ as the zero. Thus, the final volume after immersion was exclusively related to root volume.

For leaf area analysis, a 7.2- $\mathrm{cm}^{2}$-diameter puncher was used to randomly collect five leaf samples, which were then dried in a forced-air oven $\left(65^{\circ} \mathrm{C}\right.$ for $\left.72 \mathrm{~h}\right)$ along with the rest of the leaves, to obtain the total leaf dry matter. The weight and area of the sampled parts and the total leaf dry matter were used to estimate, by proportion, the total leaf area per plant.

In the analysis of dry weight of the vegetative parts, the materials were separately collected and dried in a forced-air oven $\left(65^{\circ} \mathrm{C}\right.$ for $\left.72 \mathrm{~h}\right)$. Then, the dried samples were weighed and the data were converted to g per plant.

For the analysis of nutrient contents in the leaf tissues, samples were collected in middle third of the leaf attached to the bottom of the ear. After dried and ground, the samples were analyzed for $\mathrm{N}, \mathrm{P}, \mathrm{K}, \mathrm{Ca}, \mathrm{Mg}, \mathrm{S}, \mathrm{Cu}, \mathrm{Fe}, \mathrm{Mn}$ and $\mathrm{Zn}$, using the methodology described by Malavolta et al. (1997).

The initial data were subjected to Kolmogorov-Smirnov test ( $p>0.05$ ), to evaluate sample normality. Then, the data were subjected to analysis of variance $(\mathrm{p}<0.05 ; \mathrm{p}<0.01)$ using the statistical program SISVAR (Ferreira, 2011). If significant effect was found by $\mathrm{F}$ test, means were compared by Scott-Knott test. 


\section{Results AND Discussion}

For the agronomic components (plant height - $\mathrm{PH}$, ear insertion height - EIH, stem diameter - SD, root volume $\mathrm{RV}$, leaf area - LA, root dry matter - RDM, shoot dry matter - StDM, leaf dry matter - LDM, tassel dry matter - TsDM, shoot dry matter - ShDM and total dry matter - TDM) of maize cultivated in a greenhouse, no significant response ( $p$ $>0.05$ ) was found in any of the variables analyzed (Table 1).

The absence of response found in the present study agrees with the data of Bartchechen et al. (2010), Domingues Neto et al. (2013) and Pandolfo et al. (2015), evaluating the effect of $A$. brasilense inoculation on the production components and yield of maize. Likewise, lack of response to A. brasilense inoculation has been found for other crops, such as beans (Gitti et al., 2012a), rice (Gitti et al., 2012b) and wheat (Galindo et al., 2015a, b).

For the forms and doses of $A$. brasilense inoculation (leaves, soil or seeds) in the maize crop, absence of response has also been reported in the literature, for example by Martins et al. (2012), evaluating inoculation through leaves or seeds, and Berezoski et al. (2013), evaluating inoculation through furrow, leaves and seeds. These authors did not find significant effect for the form of inoculation, just like Domingues Neto et al. (2013), in second-crop green corn, who did not observe effect for the doses of $A$. brasilense inoculation.

Lack of effect for foliar inoculation has also been found by Galindo et al. (2015b), who studied the wheat crop and found absence of response to foliar inoculation in the analyzed variables (plant height, ear length, spikelets per ear, number of empty grains, 100-grain weight, hectoliter weight, ears per meter and grain yield). The authors also conclude that there was no response to foliar inoculation, regardless of inoculation period.

The literature diverges regarding the actual effectiveness of the use of $A$. brasilense, and there are studies with positive responses to the use of inoculation or without significant responses, as in the present study. These divergences of response may be associated with the different conditions of cultivation, as mentioned by Novakowiski et al. (2011). Nonetheless, another factor that may contribute to the different responses to inoculation is the hybrid used, because some hybrids are more responsive to inoculation than others.

This effect is better explained by Revolti (2014) and Pereira et al. (2015), who studied the influence of genotypes on A. brasilense inoculation and concluded that the response to inoculation varies according to the genotypes used, i.e., hybrids influence the response to inoculation. For Bárbaro et al. (2008), it is still necessary to select strains adapted to the local edaphoclimatic conditions, and crops and their cultivars used in each region. Thus, it is believed that the absence of response here may have occurred because the hybrid (DKB 350) does not make symbiosis efficiently with $A$. brasilense, or the strains used $\left(\mathrm{AbV}_{5}\right.$ and $\left.\mathrm{AbV}_{6}\right)$ are not effective for the studied region. Nevertheless, the response to $A$. brasilense inoculation is expected to be better noted as cultivars and strains are selected to culminate in better interspecific symbiosis, for the specific edaphoclimatic conditions.

For the nutrients in the leaf tissue (Table 2), there was no difference in the contents of $\mathrm{N}, \mathrm{P}, \mathrm{K}, \mathrm{Ca}, \mathrm{Mg}, \mathrm{Cu}, \mathrm{Fe}$ and $\mathrm{Mn}$. Significant effect $(\mathrm{p}<0.05)$ was found only for $\mathrm{Zn}$ contents in maize leaf tissue, which were higher in the treatments Seed 1x; Leaf 1x; and Seed + Leaf, compared with the Control; Seed 2x; Soil 1x; Soil 2x; Leaf 2x.

In general, few effects were observed on the contents of nutrients in the leaf tissues, including leaf $\mathrm{N}$ content, which was expected to increase because some studies have highlighted that the use of $A$. brasilense, despite not replacing $\mathrm{N}$ fertilization, can influence the partial reduction of the fertilization, as observed by Araújo et al. (2014). Gitti et al. (2012b) found that, in the absence of $\mathrm{N}$ supply as top-dressing, seed inoculation with $A$. brasilense led to better $\mathrm{N}$ nutrition. However, for Pereira et al. (2015), the effect of inoculation on $\mathrm{N}$ content must be carefully analyzed, because the response to inoculation is intrinsic to each genotype used and cannot be used as a general rule.

For the other nutrients ( $\mathrm{P}, \mathrm{K}, \mathrm{Ca}, \mathrm{Mg}, \mathrm{S}, \mathrm{Cu}, \mathrm{Fe}, \mathrm{Mn}$ and $\mathrm{Zn}$ ), initially, increments in the contents in the leaf tissue could be expected, since Tien et al. (1979), in a pioneer study on A. brasilense inoculation, reported that inoculation led to substantial growth in the root system, and all lateral roots were densely covered by root hairs. Also, according to the authors, all the benefits resulting from inoculation come from the induction of the production of the phytohormone Indoleacetic Acid (IAA). However, in the present work, no significant effect was found on both root volume and root dry matter (Table 1) or on the leaf contents of $\mathrm{P}, \mathrm{K}, \mathrm{Ca}, \mathrm{Mg}, \mathrm{S}, \mathrm{Cu}, \mathrm{Fe}$ and $\mathrm{Mn}$; however, significant effect was found only on leaf $\mathrm{Zn}$ content.

The effect on leaf $\mathrm{Zn}$ content may be related to that found by Tien et al. (1979). According to Kirkby \& Römheld (2007),

Table 1. Means of plant height $(\mathrm{PH})$, ear insertion height $(\mathrm{EIH})$, stem diameter $(\mathrm{SD})$, root volume (RV), leaf area (LA) and root (RDM), stem (StDM), leaf (LDM), tassel (TsDM), shoot (ShDM) and total dry matters (TDM) in the maize crop cultivated in greenhouse, as influenced by doses and forms of $A$. brasilense inoculation

\begin{tabular}{|c|c|c|c|c|c|c|c|c|c|c|c|}
\hline \multirow{2}{*}{ Treatments } & $\mathrm{PH}$ & EIH & \multirow{2}{*}{$\begin{array}{l}\text { SD } \\
\mathrm{mm}\end{array}$} & \multirow{2}{*}{$\begin{array}{c}\text { RV } \\
\mathrm{mL}^{\text {plant }}{ }^{-1}\end{array}$} & \multirow{2}{*}{$\begin{array}{c}\text { LA } \\
\mathrm{cm}^{2} \text { plant }^{-1}\end{array}$} & RDM & StDM & LDM & TsDM & ShDM & TDM \\
\hline & & & & & & \multicolumn{6}{|c|}{ g plant ${ }^{-1}$} \\
\hline Control & $184.8^{\mathrm{ns}}$ & $96.5^{\text {ns }}$ & $17.1^{\text {ns }}$ & $38.5^{\mathrm{ns}}$ & $623.3^{\mathrm{ns}}$ & $10.7^{\text {ns }}$ & $28.2^{\text {ns }}$ & $19.1^{\text {ns }}$ & $3.1^{\mathrm{ns}}$ & $50.4^{\mathrm{ns}}$ & $61.2^{\text {ns }}$ \\
\hline Seed 1x & 168.7 & 87.7 & 17.8 & 25.3 & 594.3 & 6.3 & 18.5 & 18.0 & 1.1 & 37.6 & 43.9 \\
\hline Seed 2x & 192.0 & 99.3 & 17.5 & 37.3 & 648.1 & 12.2 & 38.7 & 21.0 & 3.1 & 62.8 & 75.0 \\
\hline Soil 1x & 177.3 & 91.0 & 17.3 & 39.5 & 605.6 & 11.1 & 21.2 & 17.4 & 2.1 & 40.8 & 51.9 \\
\hline Soil 2x & 177.3 & 91.0 & 17.4 & 32.5 & 657.8 & 9.6 & 24.4 & 18.1 & 2.4 & 44.8 & 54.5 \\
\hline Leaf $1 x$ & 189.0 & 95.8 & 16.6 & 41.5 & 664.6 & 13.2 & 25.7 & 19.1 & 2.6 & 47.5 & 60.6 \\
\hline Leaf $2 x$ & 183.8 & 107.5 & 17.5 & 50.5 & 723.3 & 11.6 & 37.3 & 19.3 & 1.6 & 58.2 & 69.8 \\
\hline Seed + Leaf & 190.8 & 102.2 & 16.4 & 31.0 & 647.3 & 7.7 & 35.0 & 18.1 & 2.2 & 55.3 & 63.0 \\
\hline C.V. (\%) & 13.0 & 14.9 & 7.7 & 34.8 & 15.5 & 51.7 & 48.4 & 17.6 & 49.8 & 34.2 & 34.0 \\
\hline
\end{tabular}

ns Not significant $(p>0.05)$ 
Table 2. Contents of nutrients (N, P, K, Ca, Mg, S, Cu, Fe Mn and $\mathrm{Zn}$ ) in the leaf tissue of maize cultivated in greenhouse as influenced by forms and doses of $A$. brasilense inoculation

\begin{tabular}{|c|c|c|c|c|c|c|c|c|c|c|}
\hline \multirow{2}{*}{ Treatments } & $\bar{N}$ & $\mathbf{P}$ & $\bar{K}$ & $\mathrm{Ca}$ & $\mathrm{Mg}$ & $S$ & $\mathrm{Cu}^{\#}$ & $\mathrm{Fe}$ & $M n$ & $\mathrm{Zn}$ \\
\hline & \multicolumn{6}{|c|}{$\mathrm{g} \mathrm{kg}^{-1}$} & \multicolumn{4}{|c|}{$\mathrm{mg} \mathrm{kg}^{-1}$} \\
\hline Control & $24.3^{\text {ns }}$ & $2.2^{\mathrm{ns}}$ & $22.0 \mathrm{~ns}$ & 3. $4^{\text {ns }}$ & $2.1^{\text {ns }}$ & $1.6^{\mathrm{ns}}$ & $30.5^{\text {ns }}$ & $98.7 \mathrm{~ns}$ & $47.3^{\mathrm{ns}}$ & $28.7 b^{*}$ \\
\hline Seed $1 x$ & 28.3 & 1.8 & 26.0 & 2.8 & 1.8 & 2.0 & 18.0 & 116.7 & 46.0 & $32.0 \mathrm{a}$ \\
\hline Seed $2 x$ & 21.1 & 1.7 & 21.0 & 2.3 & 1.3 & 1.7 & 39.8 & 80.7 & 38.0 & $27.3 \mathrm{~b}$ \\
\hline Soil $1 \mathrm{x}$ & 25.4 & 2.4 & 23.0 & 2.6 & 1.9 & 1.9 & 26.5 & 106.0 & 36.7 & $27.3 b$ \\
\hline Soil $2 x$ & 21.0 & 1.6 & 21.0 & 2.3 & 1.3 & 2.0 & 17.3 & 114.0 & 30.0 & $27.0 \mathrm{~b}$ \\
\hline Leaf $1 x$ & 24.6 & 2.0 & 22.0 & 3.1 & 1.8 & 1.9 & 29.5 & 90.7 & 55.0 & $30.7 \mathrm{a}$ \\
\hline Leaf 2x & 22.4 & 1.9 & 21.0 & 2.5 & 1.4 & 1.6 & 29.5 & 103.3 & 32.0 & $25.3 b$ \\
\hline Seed + Leaf & 26.6 & 2.2 & 21.0 & 2.9 & 1.7 & 2.1 & 17.0 & 112.7 & 39.3 & $31.3 \mathrm{a}$ \\
\hline C.V. (\%) & 15.6 & 22.0 & 11.2 & 19.4 & 26.1 & 16.2 & 30.9 & 21.6 & 31.5 & 9.2 \\
\hline
\end{tabular}

${ }^{n s}$ Not significant $(p>0.05)$; ${ }^{*}$ Means followed by the same letter do not differ by Scott-Knott test $(p<0.05)$; ${ }^{*}$ Data corrected, exclusively for the analysis, following the equation $(x+0.5)^{0.5}$

the IAA metabolism is closely related to $\mathrm{Zn}$ because IAA production requires $\mathrm{Zn}$ to produce tryptophan, which is a precursor of IAA. In other words, when Zn deficiency occurs, IAA is not synthesized. The reason for this increment in $\mathrm{Zn}$ contents is well known, but this effect may be correlated with the induction of IAA production by the A. brasilense inoculation, leading to greater need for $\mathrm{Zn}$ by the crop.

Absence of effect of $A$. brasilense foliar inoculation on plant nutrition has also been found by Galindo et al. (2015a) in the wheat crop. For maize, unlike the present study, Hungria et al. (2010) observed significant effect of A. brasilense inoculation on $\mathrm{N}, \mathrm{P}, \mathrm{K}, \mathrm{Zn}, \mathrm{Fe} \mathrm{Cu}$ and $\mathrm{B}$ contents in the leaves and on $\mathrm{P}, \mathrm{K}, \mathrm{Mg}$, $\mathrm{S}, \mathrm{Zn}, \mathrm{Mn}, \mathrm{Fe}, \mathrm{Cu}$ and $\mathrm{B}$ contents in grain tissues. Nevertheless, it is important to point out that the edaphoclimatic conditions in the study of Galindo et al. (2015a) are close to those in the present study, differing from those in the study of Hungria et al. (2010), whose experiments were carried out in the southern region of the country (Londrina and Ponta Grossa).

For the variables discussed above and the data found in the literature, it is clear the existence of influences external to the inoculation that are still not understood. However, it is noticeable that the response to inoculation depends on the symbiotic relationship between the strain and the genotype used. Consequently, it is relevant to design improvement programs of hybrids aimed at developing genotypes more responsive to inoculation because current research studies look for yield increment, which may be associated with the use of A. brasilense, coupled to the selection of hybrids. Likewise, it is notorious the need for selecting strains for the more specific edaphoclimatic conditions.

\section{Conclusion}

The forms of application (seed, soil, leaves or seed + leaves) and the doses (recommended dose or double the recommended dose) of Azospirillum brasilense inoculant $\left(\mathrm{AbV}_{5}\right.$ and $\left.\mathrm{AbV}_{6}\right)$ in the maize crop (hybrid DKB 350) did not influence the evaluated characteristics and contents of nutrients in the leaf tissue, except $\mathrm{Zn}$ content.

\section{Literature Cited}

Araújo, R. M.; Araújo, A. S. F. de; Nunes, L. A. P. L.; Figueiredo, M. do V. B. Resposta do milho verde à inoculação com Azospirillum brasilense e níveis de nitrogênio. Ciência Rural, v.44, p.1556-1560, 2014. https://doi.org/10.1590/0103-8478cr20130355
Baldani, J. I.; Caruso, L.; Baldani, V. L. D.; Goi, S. R.; Döbereiner, J. Recent advances in BNF with non-legume plants. Soil Biology \& Biochemistry, v.29, p.911-922, 1997. https://doi.org/10.1016/ S0038-0717(96)00218-0

Bárbaro, I. M.; Brancalião, S. R.; Ticelli, M. É possível a fixação biológica de nitrogênio no milho? 2008. Available in: <http://www. infobibos.com/Artigos/2008_2/fixacao/index.htm>.

Bartchechen, A.; Fiori, C. C. L.; Watanabe, S. H.; Guarido, R. C. Efeito da inoculação de Azospirillum brasiliense na produtividade da cultura do milho (Zea mays L.). Campo Digit@l, v.5, p.56-59, 2010.

Bashan, Y.; Holguin, G.; Bashan, L. E. de. Azospirillum-plant relationships: Physiological, molecular, agricultural, and environmental advances (1997-2003). Canadian Journal of Microbiology, v.50, p.521-577, 2004. https://doi.org/10.1139/ w04-035

Berezoski, R.; Novakowiski, J. H.; Follmann, D. D.; Zambonin, G.; Siega, P.; Rosa, F. T.; Sandini, I. E. Aplicação de Azospirillum brasilense na cultura do milho via semente, foliar ou sulco de semeadura. In: Encontro Anual de Iniciação Científica, 22, 2013, Foz do Iguaçu. Anais... Encontro Anual de Iniciação Científica, 2013.

CONAB - Companhia Nacional de Abastecimento. Acompanhamento da safra brasileira de grãos: Safra 2015/16. Brasília: CONAB, 2015. 166p.

Costa, M. R.; Cavalheiro, J. C. T.; Goulart, A. C. P.; Mercante, F. M. Sobrevivência de Bradyrhizobium japonicum em sementes de soja tratadas com fungicidas e os efeitos sobre a nodulação e a produtividade da cultura. Summa Phytopathologica, v.39, p.186192, 2013. https://doi.org/10.1590/S0100-54052013000300007

Dartora, J.; Guimarães, V. F.; Marini, D.; Pinto Júnior, A. S.; Cruz, L. M.; Mensch, R. Influência do tratamento de sementes no desenvolvimento inicial de plântulas de milho e trigo inoculados com Azospirillum brasilense. Scientia Agraria Paranaensis, v.12, p.175-181, 2013. https://doi.org/10.18188/1983-1471/sap. v12n3p175-181

Domingues Neto, F. J.; Yoshimi, F. K.; Garcia, R. D.; Miyamoto, Y. R.; Domingues, M. C. S. Desenvolvimento e produtividade do milho verde safrinha em resposta à aplicação foliar com Azospirillum brasilense. Enciclopédia Biosfera, v.9, p.1030-1040, 2013.

Ferreira, A. S.; Pires, R. R.; Rabelo, P. G.; Oliveira, R. C.; Luz, J. M. Q.; Brito, C. H. Implications of Azospirillum brasilense inoculation and nutrient addition on maize in soils of the Brazilian Cerrado under greenhouse and field conditions. Applied Soil Ecology, v.72, p.103-108, 2013. https://doi.org/10.1016/j.apsoil.2013.05.020 
Ferreira, D. F. Sisvar: A computer statistical analysis system. Ciência e Agrotecnologia, v.35, p.1039-1042, 2011. https://doi.org/10.1590/ S1413-70542011000600001

Galindo, F. S.; Ludkiewicz, M. G. Z.; Bellote, J. L. M.; Santini, J. M. K.; Alves, C. J.; Teixeira Filho, M. C. M. Efeito de épocas de aplicação foliar de Azospirillum brasilense nos teores de nutrientes do trigo irrigado. Revista Tecnologia \& Ciência Agropecuária, v.9, p.3742, 2015a.

Galindo, F. S.; Ludkiewicz, M. G. Z.; Bellote, J. L. M.; Santini, J. M. K.; Teixeira Filho, M. C. M.; Buzetti, S. Épocas de inoculação de Azospirillum brasilense via foliar afetando a produtividade da cultura do trigo irrigado. Revista Tecnologia \& Ciência Agropecuária, v.9, p.43-48, 2015b.

Gitti, D. C.; Arf, O.; Kaneko, F. H.; Rodrigues, R. A. F.; Buzetti, S.; Portugal, J. R.; Corsini, D. C. D. C. Inoculação de Azospirillum brasilense em cultivares de feijões cultivados no inverno. Revista Agrarian, v.5, p.36-46, 2012a.

Gitti, D. C.; Arf, O.; Portugal, J. R.; Corsini, D. C. D. C.; Rodrigues, R. A. F.; Kaneko, F. H. Coberturas vegetais, doses de nitrogênio e inoculação de sementes com Azospirillum brasilense em arroz de terras altas no sistema plantio direto. Bragantia, v.71, p.509517, 2012b. https://doi.org/10.1590/S0006-87052013005000002

Hungria, M.; Campo, R. J.; Souza, E. M.; Pedrosa, F. O. Inoculation with selected strains of Azospirillum brasilense and A. lipoferum improves yields of maize and wheat in Brazil. Plant and Soil, v.331, p.413-425, 2010. https://doi.org/10.1007/s11104-009-0262-0

Kirkby, E. A.; Römheld, V. Micronutrientes na fisiologia de plantas: funções, absorção e mobilidade. 1.ed. Piracicaba: IPNI, 2007. 24p.

Malavolta, E; Vitti, G. C.; Oliveira, S. A. Fundações. In: Malavolta, E.: Vitti, G. C.; Oliveira, S. A. (ed.). Avaliação do estado nutricional das plantas: Princípios e aplicações. 2.ed. Piracicaba: Associação Brasileira para a Pesquisa da Potassa e do Fosfato, 1997. 319p.

Martins, F. A. D.; Andrade, A. T.; Condé, A. B. T.; Godinho, D. B.; Caixeta, C. G.; Costa, R. L. Avaliação de híbridos de milho inoculados com Azospirillum brasilense. Pesquisa Agropecuária Gaúcha, v.18, p.113-128, 2012.
Novakowiski, J. H.; Sandini, I. E.; Falbo, M. K.; Moraes, A.; Novakowiski, J. H.; Cheng, N. C. Efeito residual da adubação nitrogenada e inoculação de Azospirillum brasilense na cultura do milho. Semina: Ciências Agrárias, v.32, p.1687-1698, 2011. https:// doi.org/10.5433/1679-0359.2011v32n4Sup1p1687

Pandolfo, C. M.; Vogt, G. A.; Balbinot Júnior, A. A.; Gallotti, G. J. M.; Zoldan, S. R. Desempenho de milho inoculado com Azospirillum brasilense associado a doses de nitrogênio em cobertura. Agropecuária Catarinense, v.27, p.94-99, 2015.

Pereira, C. E.; Oliveira, J. A.; Costa Neto, J.; Moreira, F. M. S.; Vieira, A. R. Tratamentos inseticida, peliculização e inoculação de sementes de soja com rizóbio. Revista Ceres, v.57, p.653-658, 2010. https:// doi.org/10.1590/S0034-737X2010000500014

Pereira, L. de M.; Pereira, E. de M.; Revolti, L. T. M.; Zingaretti, S. M.; Môro, G. V. Seed quality, chlorophyll content index and leaf nitrogen levels in maize inoculated with Azospirillum brasilense. Revista Ciência Agronômica, v.46, p.630-637, 2015. https://doi. org/10.5935/1806-6690.20150047

Raij B. van; Andrade J. C.; Cantarella H.; Quaggio J. A. (ed.). Análise química para avaliação da fertilidade de solos tropicais. Campinas: Instituto Agronômico, 2001. 285p.

Revolti, L. T. M. Interação genótipo vs formas de inoculação com Azospirillum brasilense em milho. Jaboticabal: UNESP, 2014 46p. Dissertação Mestrado

Sala, V. M. R.; Cardoso, E. J. B. N.; Freitas, J. G.; Silveira, A. P. D. Resposta de genótipos de trigo à inoculação de bactérias diazotróficas em condições de campo. Pesquisa Agropecuária Brasileira, v.42, p.833842, 2007. https://doi.org/10.1590/S0100-204X2007000600010

Santos, H. G. dos; Jacomine, P. K. T.; Anjos, L. H. C. dos; Oliveira, V. A. de; Lumbreras, J. F.; Coelho, M. R.; Almeida, J. A. de; Cunha, T. J. F.; Oliveira, J. B. de (ed.). Sistema brasileiro de classificação de solos. 3.ed. Brasília: EMBRAPA, 2013. 353p.

Tien, T. N.; Gaskins, M. H.; Hubbell, D. H. Plant growth substances produced by Azospirillum brasilense and their effect on the growth of pearl millet (Pennisetum americanum L.). Applied and Environmental Microbiology, v.37, p.1016-1024, 1979. 